\title{
Az albumin prognosztikai jelentősége az onkológiában
}

\author{
Deme Dániel dr. ${ }^{1}$ - Telekes András dr. ${ }^{1,2}$ \\ ${ }^{1}$ Szent Lázár Megyei Kórház, Onkológiai Osztály, Salgótarján \\ ${ }^{2}$ Semmelweis Egyetem, Általános Orvostudományi Kar, Geriátriai Tanszéki Csoport, Budapest
}

\begin{abstract}
A szérumalbuminszint csökkenése figyelhető meg gyulladásos folyamatokban. A helyileg előrehaladott vagy áttétes rosszindulatú daganatokban a szérumalbuminszint ugyancsak csökken, az alultápláltság fennállásától függetlenül. A csökkent albuminszint befolyásolhatja a terápia eredményeit is (például gyógyszerek farmakokinetikája, mellékhatások mértéke). Kiterjedt szakirodalmi adat és gyakorlati tapasztalat bizonyítja a táplálásterápiában részesülő páciensek jobb prognózisát. A szerzők a fontosabb szakirodalmi adatok alapján összefoglalják azon vizsgálatokat, melyek a kiindulási szérumalbuminszint és a rosszindulatú daganatos betegségek prognózisa közötti szoros összefüggést feltárták.
\end{abstract}

Orv Hetil. 2018; 159(3): 96-106.

Kulcsszavak: albumin, rosszindulatú daganatok, prognózis

\section{Prognostic importance of albumin in oncology}

Diminished serum albumin level can be observed in inflammatory processes. Serum albumin level also reduces - irrespective of the presence of malnutrition - in locally advanced or metastatic malignancies. Low serum albumin level may have an influence also on the results of anticancer therapy (e.g., drug pharmacokinetics, adverse drug reactions). Extensive data of the literature and empirical experience prove the better prognosis of patients involved in nutritional therapy. Based on the most relevent data of the literature, the authors summarize the studies which have revealed the close correlation between the baseline serum albumin level and the prognosis of malignant diseases.

Keywords: albumin, malignant diseases, prognosis

Deme D, Telekes A. [Prognostic importance of albumin in oncology]. Orv Hetil. 2018; 159(3): 96-106.

(Beérkezett: 2017. augusztus 11.; elfogadva: 2017. szeptember 29.)

\begin{abstract}
Rövidítések
$\mathrm{ALI}=$ (advanced lung cancer inflammation index) elörehaladott tüdőrák index; APACHE $=($ acute physiology and chronic health evaluation) heveny élettani és idült egészség értékelés; $\mathrm{BC}=($ breast cancer $)$ emlőrák; $\mathrm{BMI}=$ (body mass index $)$ testtömegindex $\left(\mathrm{kg} / \mathrm{m}^{2}\right) ; \mathrm{CI}=$ konfidenciaintervallum; CRC = (colorectal cancer) vastag- és végbélrák; $\mathrm{CRP}=\mathrm{C}$-reaktív protein; $\mathrm{CRPC}=$ (castration-resistant prostate cancer) kasztrációrezisztens prostatarák; CSS $=$ (cancer specific survival) daganatspecifikus túlélés; DFS = (disease-free survival $)$ betegségmentes túlélés; DNS = dezoxiribonukleinsav; DSS = (disease-specific survival) betegségspecifikus túlélés; GPS = (Glasgow Prognostic Score) Glasgow prognosztikai pontrendszer; HCC = (hepatocellular carcinoma) primer májrák; $\mathrm{HR}=$ (hazard ratio) kockázati hányados; IL = interleukin; IMA = ischaemiamódosított albumin; IPI = (inflammatory prognostic index $)$ gyulladásos
\end{abstract}

prognosztikai index; KPS = Karnofsky Performance Status; $\mathrm{LDH}=$ (lactate dehydrogenase) laktátdehidrogenáz; LMR = (lymphocyte-monocyte ratio) abszolút lymphocyta-monocyta arány; mGPS $=($ modified Glasgow Prognostic Score $)$ módosított Glasgow prognosztikai pontrendszer; mGPS 0, 1, 2 = a módosított Glasgow prognosztikai pontrendszer értékei 0,1 , 2 ; MSKCC $=$ Memorial Sloan Kettering Cancer Center; nabpaclitaxel = nanopartikuláris albuminhoz kötött paclitaxel; NLR = (neutrophil-lymphocyte ratio) abszolút neutrophillymphocyta arány; NRS = (nutritional risk screening) tápláltsági kockázatszürés; NSCLC $=$ (non-small cell lung cancer $)$ nem kissejtes tüdőrák; OS = (overall survival) teljes túlélés; PFS = (progression-free survival) progressziómentes túlélés; PLR = (platelet-lymphocyte ratio) vérlemezke-abszolút lymphocyta arány; $\mathrm{PNI}=($ prognostic nutritional index $)$ prognosztikai tápláltsági index; $\mathrm{RCC}=($ renal cell carcinoma $)$ veserák; RFS $=$ 
(recurrence-free survival) kiújulásmentes túlélés; ROS = (reactive oxygen species) reaktív oxigéngyökök; $S D=$ standard deviáció; SIS = (systemic inflammation score) szisztémás gyulladásos pontrendszer; SIS $0,1,2=$ szisztémás gyulladásos pontrendszer értékei $0,1,2$; SOFA = (sequential organ failure assessment) szekvenciális szervelégtelenség felmérése; STS = lágyrész-sarcoma; $\mathrm{TNF}=$ tumornekrózis-faktor; $\mathrm{TNM}=\mathrm{tu}-$ mor nodus metastasis

Az albumin a szérumfehérjéknek megközelítóleg a 60\%át teszi ki, jelen van a szövet közötti térben és a testfolyadékokban is. A májban naponta 9-12 g termelődik [1]. Képződését az kolloidozmotikus nyomás [2], a szervezet gyulladásos statusa és kisebb mértékben tápláltsági állapota és a hormonális tényezók határozzák meg ( 1 . ábra). Katabolizmusa pontosan nem ismert, azonban valószínúsíthetôen az érfal endothelsejtjeiben megy végbe. Fő funkciója az ozmotikus nyomás fenntartása. Negatív töltése révén, amennyiben a vér $\mathrm{pH}$-értéke a normális tartományban van, a vérplazmában tartja a nátriumionokat, és ezzel együtt a vizet. Központi szerepe van a molekulák transzportjában és a lipidanyagcserében is [1]. Az albuminnak ugyanakkor in vitro és in vivo protektív hatása is ismert. Neutralizálja a karcinogéneket, például a nitrózaminokat és az aflatoxint. Erős antioxidáns tulajdonsággal bír. Stabilizálja a dezoxiribonukleinsav (DNS)-megkettőződést. Védi a szöveteket a sugárzással szemben [3]. Az albumin intracellulárisan igen kis koncentrációban van jelen. Megközelítőleg
$0,5 \mathrm{~g}$ albumin kötődik a hepatocyták szekretoros csatornáihoz, és $0,2 \mathrm{~g}$ található a lysosomákban [4].

Az albuminmeghatározás brómkrezol festékkel, kolorimetriás eljárás keretében történik. A mérés alapja az, hogy az albumin-brómkrezol komplex más hullámhoszszú fényt nyel el, mint a szabad brómkrezol. Mivel a brómkrezol más fehérjékhez is kötődhet, a vizsgálat az albuminszint túlbecsülését okozhatja [1].

A lokalizált rosszindulatú daganatos betegeknél enyhe hypalbuminaemia vagy normális albuminszint észlelhetô. A betegség progressziója esetén azonban a testtömeg csökkenésével együtt az albuminszint is jelentős mértékben csökken. Az albuminszint csökkenése egyrészt a testtömegcsökkenéssel, másrészt a nagy mennyiségú citokintermeléssel [interleukin (IL)-1, IL-6, IL-8 és tumornekrózis-faktor (TNF)] magyarázható $[5,6]$. Kiterjedt szakirodalmi adathalmaz és gyakorlati tapasztalat támasztja alá azt a tényt, hogy helyileg előrehaladott és áttétes rosszindulatú daganatos betegségek kezelése során a prognózist előre jelzi a páciensek jó tápláltsági állapota. Ismeretes, hogy stresszállapot esetén (például perioperatív időszakban, kemo- vagy kemoradioterápia alatt) a lokalizált rosszindulatú daganatos betegekben is megelőzhető a malnutríció megfelelő táplálással. A megfelelő tápláltsági állapot elérésével biztosítható, hogy a daganatos betegség és az annak kezelése következtében fellépő katabolikus folyamat megálljon, és a szervezet energiaraktárai feltöltődjenek. Ezáltal javul az általános állapot, aminek következménye például a gyorsabb sebgyógyulás és a kemo- vagy kemoradioterápiás mellékhatások csökkenése. Ennek alapján érthető, hogy a jó tápláltsági álla-

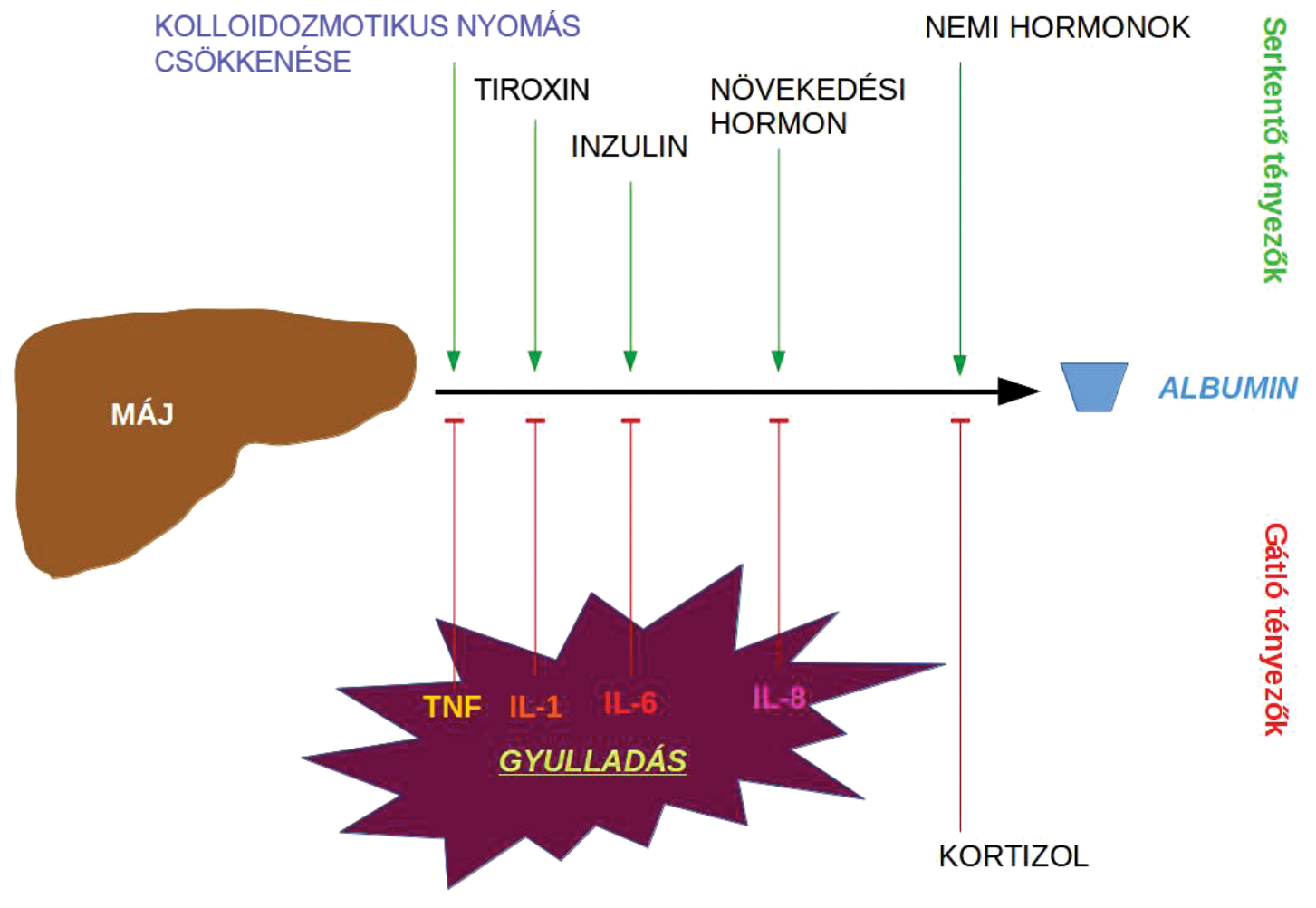

1. ábra

| Az albumin termelődését serkentő és gátló tényezők 
1. táblázat | A GPS- és a mGPS-pontrendszer kritériumai

\begin{tabular}{l|cc|cc|cc}
\hline & \multicolumn{2}{|c|}{0} & & \multicolumn{2}{c}{2} & \multicolumn{2}{c}{2} \\
\cline { 2 - 7 } & $\mathrm{CRP}(\mathrm{mg} / \mathrm{l})$ & Albumin $(\mathrm{g} / \mathrm{l})$ & $\mathrm{CRP}(\mathrm{mg} / \mathrm{l})$ & Albumin $(\mathrm{g} / \mathrm{l})$ & $\mathrm{CRP}(\mathrm{mg} / \mathrm{l})$ & Albumin $(\mathrm{g} / \mathrm{l})$ \\
\hline GPS & $\leq 10$ & $\geq 35$ & $>10$ & $<35^{*}$ & $>10$ & $<35$ \\
mGPS & $\leq 10$ & $\geq 35$ & $>10$ & $\geq 35$ & $>10$ & $<35$ \\
\hline
\end{tabular}

*GPS1: CRP > $10 \mathrm{mg} / \mathrm{l}$ VAGY albumin $<35 \mathrm{~g} / 1$, a többi esetben ÉS relációban vannak a változók (például GPS2: CRP >10 mg/1 ÉS albumin $<35 \mathrm{~g} / \mathrm{l})$.

$\mathrm{CRP}=$ C-reaktív protein; GPS = Glasgow prognosztikai pontrendszer; $\mathrm{mGPS}=$ módosított Glasgow prognosztikai pontrendszer

pot (így a magasabb albuminszint is) előre jelzi a jó terápiás választ, mivel lehetôvé teszi a páciensek hatékony kezelhetőségét.

A szérumalbuminszint számos prognosztikai pontrendszer részét képezi. A C-reaktív protein (CRP) és az albumin értékeinek figyelembevételével hozták létre a Glasgow Prognostic Score (GPS-) és a módosított GPS (mGPS-) pontrendszereket. A GPS- és a mGPS-pontrendszer kritériumait az 1. táblázatban foglaltuk össze. A CRP prognosztikai szerepét feltáró vizsgálatokat egy korábbi tanulmányunkban írtuk le, továbbá feldolgoztuk a CRP-vel együtt vizsgált számos paraméter jellemzőit is [7], melyekre a jelen közleményünkben hivatkozunk. Az albuminértékekből és az abszolút lymphocytaszámból alakították ki a prognosztikai tápláltsági indexet (PNI): $\mathrm{PNI}=\operatorname{albumin}(\mathrm{g} / \mathrm{l})+5 \times$ lymphocyta $(\mathrm{g} / \mathrm{l})[8]$. Az előrehaladott tüdórák indexet (ALI) a testtömegindex (BMI), az albuminszint és az abszolút neutrophil-lymphocyta arány (NLR) figyelembevételével számítják: ALI $=($ BMI $\times$ albumin $) /$ NLR [9]. Világossejtes veserákban a szisztémás gyulladásos pontrendszer megalkotásával (SIS) az albuminszinteknek és az abszolút lymphocytamonocyta aránynak (LMR) a kombinálásával három csoportot alkottak (2. táblázat) [10]. Ismeretes, hogy az alacsony LMR a nem áttétes világossejtes veserák mútét-

2. táblázat |A SIS-pontrendszer

\begin{tabular}{lllll}
\hline & 0 & & 1 & \\
\hline Albumin $(\mathrm{g} / \mathrm{l})$ & $\geq 40$ & $\geq 40$ & $<40$ & $<40$ \\
LMR & $\geq 4,44$ & $<4,44$ & $\geq 4,44$ & $<4,44$ \\
\hline
\end{tabular}

LMR = abszolút lymphocyta-monocyta arány; SIS = szisztémás gyulladásos pontrendszer

3. táblázat |A Tokyo-pontrendszer

\begin{tabular}{lccc}
\hline & 0 & 1 & 2 \\
\hline Albumin $(\mathrm{g} / \mathrm{dl})$ & $>3,5$ & $2,8-3,5$ & $<2,8$ \\
Bilirubin $(\mathrm{mg} / \mathrm{dl})$ & $<1$ & $1-2$ & $>2$ \\
A HCC mérete $(\mathrm{cm})$ & $<2$ & $2-5$ & $>5$ \\
A HCC-gócok száma $(\mathrm{db})$ & $\leq 3$ & $\begin{array}{c}\text { Nem adható } \\
\text { pontszám }\end{array}$ & $>3$ \\
\hline
\end{tabular}

HCC = primer májrák je elôtt rossz prognózist vetít előre $[11]$. Az alacsony LMR rossz prognosztikai szerepét lágyrész-sarcomában (STS) is igazolták [12]. Veserákban (RCC) a Memorial Sloan Kettering Cancer Center (MSKCC) kockázati modell a következő 5 tényezőt veszi figyelembe: a diagnózistól a szisztémás kezelésig eltelt idő; hemoglobinszint; kalciumszint; laktátdehidrogenáz (LDH); Karnofsky Performance Status (KPS). Az albumin hozzáadása javítja az MSKCC-modell pontosságát a túlélés elörejelzésének vonatkozásában $(\mathrm{p}<0,001)$ [13]. Az LDH prognosztikai szerepét más közleményünkben ismertettük [14]. Primer májrákban (HCC) a Child-Pugh-pontrendszertől érzékenyebbnek találták a Tokyo prognosztikai pontrendszert, mely négy tényezőt vesz figyelembe: albuminszint, bilirubinszint, a HCC mérete és a HCCgócok száma (3. táblázat) [15]. Ugyancsak HCC-ben egy másik pontrendszer szerint az ún. „albumin-bilirubin grade" számításakor a következő formulát alkalmazzák: $-0,085 \times($ albumin, $g / 1)+0,66 \times \log$ (bilirubin, $\mu \mathrm{mol} / \mathrm{l})$. Három fokozatot (gradust) különböztetnek $\operatorname{meg}$ (I. $\leq-2,60$; II. > -2,6 és $\leq-1,39$ között; III. > -1,39 [16]. A gyulladásos prognosztikai indexet (IPI) a CRP, az NLR és az albumin értékeiből számítják; IPI = $\mathrm{CRP} \times \mathrm{NLR} /$ albumin [17].

\section{Módszer}

Szakirodalmi kutatásunk során olyan tanulmányokat kerestünk, amelyek az albumin prognosztikai szerepét tárták fel különféle daganattípusokban.

\section{Eredmények}

Az alábbiakban néhány fontosabb vizsgálatot ismertetve a szerző́k rávilágítanak arra, hogy a kiindulási szérumalbuminszint és a rosszindulatú daganatos betegségek prognózisa jelentősen összefügg.

\section{Az alacsony albuminszint negatí prognosztikai szerepe a rosszindulatú daganatokban stádiumtól függetlenül}

Egy szisztematikus összefoglaló közleményben 19952009 között publikált 59 vizsgálatot elemeztek. A tanulmányok megoszlása a következő volt: 29 gastrointestina- 
lis $(\mathrm{n}=9785), 10$ tüdő $(\mathrm{n}=2179), 6$ nőgyógyászati $(\mathrm{n}=1959)$, 6 többszörös $(\mathrm{n}=1292)$ és 8 egyéb $(\mathrm{n}=1249)$ daganatos betegségeket áttekintő vizsgálatok. A legtöbb vizsgálatban a kiindulási alacsony albuminszint rövidebb túléléssel társult. A szerzők felhívták a figyelmet arra, hogy a szérumalbumin értelmezése gyakran nehéz, mert más, nem táplálkozással összefüggő tényezók - mint a hidratáltsági állapot és maga a betegség lefolyása is - hatással lehetnek az albuminszintre [18].

Egy másik összefoglaló tanulmányban 69 vizsgálat adatai alapján a GPS és a mGPS a túlélésre vonatkozólag független prognosztikai értékekkel bírt 54 vizsgálatban: 4-ben nem válogatott beteganyagon $(\mathrm{n}=16781), 28$ ban reszekálható betegség esetén $(\mathrm{n}=8333)$, 11-ben kemo- vagy radioterápián átesett páciensek esetén (n = $1504)$ és újabb 11-ben nem reszekálható betegség esetén $(\mathrm{n}=2119)$. Az összefoglaló tartalmazott 15 másik, úgynevezett asszociációs vizsgálatot $(\mathrm{n}=2223)$, melyekben a GPS/mGPS-nek nem a túlélésre vonatkozó prognosztikai szerepét tárták fel, hanem összefüggést kerestek és találtak az emelkedett GPS- vagy mGPS-értékek és a fokozott súly- és izomvesztés, rossz általános állapot, többszörös társbetegségek, emelkedett proinflammatorikus és angiogenetikus citokinek és a kezeléssel kapcsolatos szövődmények előfordulása között [19].

Szolid (vagyis nem hematológiai) daganatos betegek körében $(\mathrm{n}=296)$ az emelkedett mGPS rövidebb túléléssel korrelált. mGPSI esetén nem volt jelentős a különbség (kockázati hányados [HR] 1,346 [95\%-os konfidenciaintervallum $\{\mathrm{CI}\} \quad 0,585-3,100], \mathrm{p}=0,484)$, azonban mGPS2-nél szignifikáns különbséget találtak (HR 2,712 [95\%-os CI 1,252-5,875], p = 0,011) [20].

Hasnyálmirigyrákban több vizsgálatban keresték a GPS vagy mGPS, a NLR és a vérlemezke-abszolút lymphocyta arány (PLR) prognózissal való összefüggését. A vizsgálatok közötti átfedéseket figyelembe véve, az adatokat szisztematikusan összefoglalták. Hat vizsgálatból $(\mathrm{n}=1059) 5$-ben a GPS- és a mGPS-pontrendszerek jelentős prognosztikai szereppel bírtak -5 vizsgálatban az egyváltozós, és ebből 3 vizsgálatban mind az egyváltozós, mind a többváltozós elemzések szerint -, míg 1 vizsgálatban nem volt jelentős prognosztikai szerepe ezeknek a pontrendszereknek. Tizenegy vizsgálatból ( $\mathrm{n}=1331$ ) 6-nál a NLR emelkedésének prognosztikai jelentősége volt az egyváltozós, és ebből 4-nél a többváltozós elemzés alapján is, míg 5 vizsgálatban nem volt jelentős prognosztikai szerepe a NLR-nak. Hét vizsgálatból ( $\mathrm{n}=993$ ) 1-nél a PLR mind az egyváltozós, mind a többváltozós elemzés alapján prognosztikailag jelentős volt, míg a többi vizsgálatban nem volt jelentős prognosztikai szerepe a PLR-nek az egyváltozós elemzés alapján. Két vizsgálatból $(\mathrm{n}=445)$ az egyikben $(\mathrm{n}=268)$ a $\mathrm{PNI}<45$ érték rossz prognózisra utalt (HR 1,73 [95\%os CI 1,21-2,47], $\mathrm{p}=0,003)$, míg a másik vizsgálatban nem volt jelentős prognosztikai szerepe a PNI-nek $(\mathrm{p}=0,123)$. A szerzők arra következtettek az eredményekből, hogy a GPS/mGPS és a NLR együttes alkalma- zása értékes lehet a prognózis előrejelzésében, ennek megerósítésére azonban jól tervezett vizsgálatokra van szükség. Továbbá véleményük szerint az adatok nem támasztották alá sem a PLR, sem a PNI alkalmazását [8].

HCC-ben 10 vizsgálat metaanalízise során $(\mathrm{n}=2140)$ az emelkedett GPS rövidebb progressziómentes túléléssel (PFS) (HR 1,755 [95\%-os CI 0,943-3,265], p = 0,076) és teljes túléléssel (OS) társult (HR 2,156 [95\%-os CI 1,696-2,740], p<0,001) [21].

CRC-ben 9 vizsgálat $(\mathrm{n}=2227)$ metaanalízise alapján az emelkedett mGPS rövidebb teljes túléléssel társult (HR 1,69 [95\%-os CI 1,4-2,04], p<0,00001) [22].

Veserákban (RCC) 2003-2016 között publikált 17 vizsgálat $(\mathrm{n}=6447)$ metaanalízise alapján a kiindulási alacsony albuminszint rövidebb teljes túléléssel (HR 2,46 [95\%-os CI 1,92-3,13], p<0,001) és daganatspecifikus túléléssel (CSS) (HR 1,75 [95\%-os CI 1,28-2,38], $\mathrm{p}<0,001)$ társult [23]. Egy retrospektív vizsgálatban, világossejtes veserákban $(\mathrm{n}=44 \mathrm{l})$ az emelkedett SISpontérték rövidebb túléléssel társult: SIS1-nél HR 2,109 (95\%-os CI 1,020-4,363), p = 0,044; SIS2-nél HR 4,149 (95\%-os CI 1,980-8,695), p<0,001. A SIS-pontrendszer objektívebben tükrözi a gyulladás és az immunválasz közötti kapcsolatot, mint a NLR vagy a PLR. A szerzők javasolták a CRP-értékek és a SIS-pontrendszer prognosztikai szerepének együttes vizsgálatát [10].

Petefészekrákban $(\mathrm{n}=344)$, a mútét előtti $\mathrm{PNI}<45$ rövidebb progressziómentes (HR 1,890 [95\%-os CI 1,396-2,560], $\mathrm{p}<0,001$ ) és teljes túléléssel (HR 1,747 [95\%-os CI 1,293-2,360], p<0,001) társult [24].

\section{Az alacsony albuminszint negatí prognosztikai szerepe lokalizált rosszindulatú daganatokban}

Lokalizált (St. I, II, IIIA) nem kissejtes tüdőrák (NSCLC) $(\mathrm{n}=110)$ reszekciója után az átlag alatti $(<37,1 \mathrm{~g} / \mathrm{l})$ albuminszint rosszabb túléléssel társult (HR $0,93[0,88-0,98], \mathrm{p}=0,006)$. A páciensek átlagos BMIértéke 26,1 (standard deviáció $[\mathrm{SD}]=4,4$; a tartomány = 17-38) volt. Hét páciensnél $\mathrm{BMI} \leq 19,44$ páciensnél normális BMI-értéket (20-25) mértek, és 58 páciens túlsúlyos volt (BMI>25). A BMI nem mutatott szignifikáns összefüggést a túléléssel [25]. Korai HCC-ben ( $\mathrm{n}=$ 318) a kiindulási albumin-bilirubin grade II rosszabb OS-t vetített előre a kuratív reszekció után $(\mathrm{p}<0,001)$ [26]. Egy másik vizsgálat szerint HCC $(n=403)$ kuratív kezelése során az alacsonyabb Tokyo-pontszám hoszszabb OS-sel párosult. Az alacsonyabb albuminszintek (28-35 g/1 és <28 g/l tartományokban) rosszabb túléléssel társultak (HR 1,74 [95\%-os CI 1,31-2,30]; p = 0,00014 és 2,45 [95\%-os CI $1,55-3,88$ ]; $\mathrm{p}=0,00013$ ) [15]. Cardiadaganat $(\mathrm{n}=314)$ mútétje előtt mért magasabb albuminszint (>35 g/l) alacsonyabb perioperatív mortalitással és morbiditással társult, és hosszabb volt az 5 éves OS is $(\mathrm{p}=0,0003)$. A szerzők posztoperatív táplálási támogatást javasoltak a preoperatíve észlelt alacsonyabb albuminszint esetén [27]. Gyomorrák ( $\mathrm{n}=1023)$ 
kuratív reszekciója esetén (266 fó) négy albumintartománynak (igen alacsony: $\leq 28 \mathrm{~g} / \mathrm{l}$; alacsony: 28,1-32,9 g/l; közepes: 33-37,3 g/l; magas: $\geq 37,4 \mathrm{~g} / \mathrm{l}$ ) és a túlélésnek az összefüggéseit vizsgálták az egyes stádiumokban. A magasabb albuminszintek hosszabb túléléssel párosultak. Az egyes tartományokra vonatkozó HR-értékek a következők voltak: 2,47 (95\%-os CI 1,28-4,76), p = 0,$007 ; 1,62(95 \%$-os CI $0,69-3,06), \mathrm{p}=0,3 ; 1,12$ (95\%-os CI 0,55-2,3), p = 0,7; 1 (ez a magas tartomány volt a viszonyítási alap, ezért nincs $\mathrm{CI}$ ), $\mathrm{p}=0,04$ [28]. A vizsgálatból látható, hogy az igen alacsony albuminszint bizonyult a HR szempontjából a legrosszabbnak. Lokalizált CRC-ben $(\mathrm{n}=332)$, a szérumalbuminszint, az életkor, a betegség helyi kiújulása és a rosszindulatú daganat differenciációja a túlélés független prognosztikai faktorainak bizonyultak. A stádiumok növekedésével (Dukes A, B és C) egyre alacsonyabb átlagos albuminszinteket találtak (>45 g/1; 35-44 g/1; 25-34 g/l). Az albuminra vonatkozó arányos kockázat (vagyis a HR) 0,94 (95\%-os CI 0,9l-0,97; p<0,0002) volt [29]. Dukes B-stádiumú CRC-ben $(\mathrm{n}=159)$ az alacsonyabb mGPS esetén hosszabb túlélést találtak. A 3 éves túlélés a mGPS 0., 1. és 2. csoportjában $92 \%, 71 \%$ és $72 \%$ (p = $0,0035)$ volt [30]. Reszekábilis méhnyakrákban ( $\mathrm{n}=$ 795 ) a szérumalbuminszint (más faktorok mellett, mint a BMI, vérlemezkeszám, fehérvérsejtszám, a daganat differenciáltsági foka és a kismedencei nyirokcsomóstatus) az OS független prognosztikai faktorának bizonyult $(\mathrm{p}<0,05)[31]$. Epithelialis ovarium carcinoma $(\mathrm{n}=213)$ minden stádiumában rosszabb túlélés társult $(\mathrm{p}<0,001)$ az alacsony albuminszinttel $(\leq 35 \mathrm{~g} / \mathrm{l})$ [32] - ezt a tényt más szerzők korábban már prognosztikai modellekkel is leírták [33]. A vizsgálatban a BMI nem mutatott szignifikáns összefüggést a túléléssel [32]. STS-ben $(\mathrm{n}=61)$ a páciensek 64\%-ának I-II-III. stádiumú betegsége volt, és az albuminszint az OS független prognosztikai faktorának bizonyult minden stádiumban. Alacsony albuminszint $(<35 \mathrm{~g} / \mathrm{l})$ esetén a p-érték egyváltozós analízisben 0,03, míg többváltozós analízisben 0,02 volt. A BMI nem volt prognosztikus értékű [34]. Alacsony albuminszintet $(<40 \mathrm{~g} / 1)$ találtak I-II-III. stádiumú világossejtes veserákban $(\mathrm{n}=335) 112$ páciensnél. Ebben a csoportban az OS szignifikánsan rövidebb volt $(\mathrm{p}<0,001)$ [10]. Más vizsgálat szerint RCC-ben $(\mathrm{n}=962)$ 20\%-ban találtak alacsony albuminszintet. A páciensek $60 \%$-ának lokalizált betegsége volt. A hypoalbuminaemia esetén roszszabb betegségmentes túlélést találtak (HR 2,3 [CI nem volt megadva]; $\mathrm{p}<0,0001)$ [35]. RCC-ben $(\mathrm{n}=15 \mathrm{l})$ $40 \%$-ban találtak alacsony albuminszintet. A páciensek 66,8\%-a I-II-III. stádiumban volt. A hypoalbuminaemia rosszabb betegségmentes túléléssel korrelált a stádiumra illesztve (HR 3,00 [CI 0,99-8,87], p = 0,051) [36]. Egy emlőrákban (BC) végzett vizsgálat szerint 169 esetben nézték az albuminszinteket. Közülük 150 páciensnek lokalizált betegsége volt (St. I-II-III). Alacsony albuminszint $(<35 \mathrm{~g} / \mathrm{l})$ esetén az 5 éves túlélési arány $60 \%$ lett, míg normális albuminszint $(>35 \mathrm{~g} / \mathrm{l})$ esetén $75 \%$ volt. Az alacsony albuminszintnek nem volt kihatása a rövid távú túlélésre, azonban alacsony albuminszint esetén a 3 éves túlélés jelentősen magasabb halálozási aránnyal párosult $(\mathrm{p}=0,045)$. A BMI átlagértéke 26 volt (tartomány: $17,8-51,8)$. A BMI nem mutatott összefüggést a túléléssel [37].

\section{Az alacsony albuminszint negativ prognosztikai szerepe helyileg elörehaladott vagy áttétes rosszindulatú daganatokban}

Egy intézetben 1999-2010 között végzett 41 'fázis I' vizsgálat elemzésében, nőgyógyászati daganatokban $(\mathrm{n}=$ 184), a kiindulási alacsony albuminszint $(\leq 35 \mathrm{~g} / \mathrm{l})$ rövidebb teljes túléléssel korrelált (HR 5,01 [95\%-OS CI 2,89-8,7], p<0,001) [38].

RCC-ben $(\mathrm{n}=362)$, a kiindulási alacsony albuminszint $(\leq 35 \mathrm{~g} / \mathrm{l})$ rövidebb teljes túléléssel társult (HR 2,48 [95\%-os CI 1,87-3,30], p<0,0001). Az emelkedett abszolút neutrophilszám, a vérlemezkeszám és az NLR szignifikánsan javítja az MSKCC-rizikófaktorok alapján meghatározott prognosztikai osztályozás pontosságát [39].

Helyileg előrehaladott hólyagrákban ( $n=67)$, a kiindulási alacsony albuminszint $(<35 \mathrm{~g} / \mathrm{l})$ rövidebb progressziómentes túléléssel társult (HR 2,04 [95\%-Os CI $1,10-3,78], \mathrm{p}=0,023)$. A GPS2 rövidebb teljes túléléssel társult (HR 7,00 [95\%-os CI 2,53-19,36], p = 0,001) [40].

Áttétes kasztrációrezisztens prosztatarákban (CRPC) $(\mathrm{n}=220)$, a kiindulási alacsony albuminszint $(<35 \mathrm{~g} / \mathrm{l})$ rövidebb teljes túléléssel társult (HR 0,28 [95\%-os CI 0,14-0,56], p<0,001). A magasabb mGPS-pontszám $(\geq 1)$ is rövidebb túléléssel korrelált (HR 1,87 [95\%-os CI 1,35-2,59], p<0,001) [41].

Áttétes nem kissejtes tüdőrákban (NSCLC) $(\mathrm{n}=173)$ tanulmányozták az ALI<18 rövidebb progressziómentes (HR 1,66 [95\%-os CI 1,18-2,33], p = 0,003) és teljes túléléssel társult (HR 1,42 [95\%-os CI 1,003-2,01], p = 0,047) [9].

Sebészileg inkurábilis és áttétes CRC-ben $(\mathrm{n}=705)$ a kiindulási CRP-albumin arány a kiújulásmentes túlélés és a daganatspecifikus túlélés független prognosztikai faktorának bizonyult $(\mathrm{p}=0,025$ és $\mathrm{p}=0,045)$. Amennyiben a CRP-albumin arány $\geq 0,0271$, a kiújulásmentes túlélés és a daganatspecifikus túlélés jelentôsen rövidebb ( $\mathrm{p}=$ $0,0003$ és $\mathrm{p}=0,0026)$. Amikor a CRP-albumin arány $<0,0271$ volt, jobb kiújulásmentes túlélést és daganatspecifikus túlélést találtak a mGPS $=0$ alcsoportban, mint a magas CRP-albumin arányt mutató páciensek alcsoportjában (kiújulásmentes túlélésre $[\mathrm{RFS}] \mathrm{p}=0,0015$; daganatspecifikus túlélésre $\mathrm{p}=0,0131$ ) [42].

Egy elemzés szerint 1994-2008 között kezelt nem áttétes STS-ben szenvedő pácienseknél $(\mathrm{n}=614)$ azt találták, hogy a kiindulási csökkent albumin $(<36 \mathrm{~g} / \mathrm{l})$, hemoglobin (<117,6 g/l nőknél és <133,7 g/l férfiaknál) 
4. táblázat |Az alacsony szérumalbuminszint negatív prognosztikai szerepét feltáró fontosabb vizsgálatok a rosszindulatú daganatokban, stádiumtól függetlenül

\begin{tabular}{|c|c|c|c|c|c|}
\hline Szerző & Daganat & A vizsgálat típusa & A vizsgálatok száma & $\mathrm{n}=$ & $\begin{array}{l}\text { Az alacsony albuminszint és a rövidebb túlélés } \\
\text { összefüggése }\end{array}$ \\
\hline $\begin{array}{l}\text { Gupta D. } \\
2010[18]\end{array}$ & $\begin{array}{l}\text { Szolid (nem } \\
\text { hematológiai) }\end{array}$ & $\begin{array}{l}\text { Szisztematikus } \\
\text { összefoglalás }\end{array}$ & 59 & 16464 & A legtöbb vizsgálatban jelentős összefüggés \\
\hline $\begin{array}{l}\text { McMillan DC. } \\
2013 \text { [19] }\end{array}$ & $\begin{array}{l}\text { Szolid (nem } \\
\text { hematológiai) }\end{array}$ & $\begin{array}{l}\text { Szisztematikus } \\
\text { összefoglalás }\end{array}$ & 69 & 30960 & $\begin{array}{l}54 \text { vizsgálatban a GPS/mGPS jelentős prognoszti- } \\
\text { kai faktor }\end{array}$ \\
\hline $\begin{array}{l}\text { Partridge } M . \\
2012[20]\end{array}$ & $\begin{array}{l}\text { Szolid (nem } \\
\text { hematológiai) }\end{array}$ & Retrospektív & 1 & 296 & $\begin{array}{l}\text { mGPS1: HR } 1,346 ; \mathrm{p}=0,484 \\
\text { mGPS2: HR } 2,712 ; \mathrm{p}=0,011\end{array}$ \\
\hline $\begin{array}{l}\text { Ahmad J. } \\
2014[8]\end{array}$ & Hasnyálmirigyrák & $\begin{array}{l}\text { Szisztematikus } \\
\text { összefoglalás }\end{array}$ & 6 & 1059 & $\begin{array}{l}5 \text { vizsgálatban a GPS/mGPS jelentős prognosztikai } \\
\text { faktor }\end{array}$ \\
\hline $\begin{array}{l}\text { Ahmad J. } \\
2014[8]\end{array}$ & Hasnyálmirigyrák & $\begin{array}{l}\text { Szisztematikus } \\
\text { összefoglalás }\end{array}$ & 2 & 445 & $\begin{array}{l}\text { Az egyik vizsgálatban }(\mathrm{n}=268) \mathrm{PNI}<45: \mathrm{HR} 1,73 ; \\
\mathrm{p}=0,003\end{array}$ \\
\hline $\begin{array}{l}\text { Li MX. } \\
2015[21]\end{array}$ & $\mathrm{HCC}$ & Metaanalízis & 11 & 2140 & $\begin{array}{l}\text { A GPS jelentős prognosztikai faktor: } \\
\text { PFS-re HR } 1,755 ; \mathrm{p}=0,076 \\
\text { OS-re HR } 2,156 ; \mathrm{p}<0,001\end{array}$ \\
\hline $\begin{array}{l}\text { Petrelli F. } \\
2015[22]\end{array}$ & CRC & Metaanalízis & 9 & 2227 & $\begin{array}{l}\text { A mGPS jelentős prognosztikai faktor: } \\
\text { OS-re HR } 1,69 ; \mathrm{p}<0,00001\end{array}$ \\
\hline $\begin{array}{l}\text { Chen Z. } \\
2016[23]\end{array}$ & RCC & Metaanalízis & 17 & 6447 & $\begin{array}{l}\text { CSS-re HR } 1,75 ; \mathrm{p}<0,001 \\
\text { OS-re HR } 2,46 ; \mathrm{p}<0,001\end{array}$ \\
\hline $\begin{array}{l}\text { Chang Y. } \\
2015[10]\end{array}$ & $\begin{array}{l}\text { Világossejtes } \\
\text { veserák }\end{array}$ & Retrospektív & 1 & 441 & $\begin{array}{l}\text { SIS1: HR 2,109; } \mathrm{p}=0,044 \\
\text { SIS2: HR 4,149; }<<0,001\end{array}$ \\
\hline $\begin{array}{l}\text { Miao Y. } \\
2016[24]\end{array}$ & Petefészekrák & Retrospektív & 1 & 344 & $\begin{array}{l}\mathrm{PNI}<45 \\
\text { PFS-re HR } 1,890 ; \mathrm{p}<0,001 \\
\text { OS-re HR } 1,747 ; \mathrm{p}<0,001\end{array}$ \\
\hline
\end{tabular}

CRC = vastag- és végbélrák; CSS = daganatspecifikus túlélés; GPS = Glasgow prognosztikai pontrendszer; HCC = primer májrák; HR = kockázati hányados; mGPS = módosított Glasgow prognosztikai pontrendszer; OS = teljes túlélés; PFS = progressziómentes túlélés; PNI = prognosztikai tápláltsági index; RCC = veserák; SIS = szisztémás gyulladásos pontrendszer

és NLR emelkedése $(>5,3)$ függetlenül a rövidebb betegségspecifikus (DSS) és teljes túléléssel korrelált [43]. Az anaemia okát az IL-6 által fokozódó hepcidinemelkedés magyarázhatja [44, 45].

A fenti vizsgálatok összefoglalását a 4., 5. és 6. táblázat tartalmazza.

\section{Megbeszélés}

A helyileg előrehaladott vagy áttétes rosszindulatú daganatokban a kiindulási albuminszint rosszabb prognózist vetít előre. Számos vizsgálat stádiumtól független összefüggést talált az alacsony albuminszint és a rosszabb túlélés között.

A Tumor Nodus Metastasis (TNM-) rendszer stádiumbeosztása nem feltétlenül korrelál a prognózissal. Nem mondható ki például, hogy a TNM II. stádiumú CRC jobb prognózisú, mint a III. stádiumú CRC, mivel a II. stádiumú csoportba a helyileg előrehaladott (T4b) daganat is beletartozik (így IIC stádiumot kapva), mely nagy valószínúséggel irreszekábilis. Ugyanakkor, ha egy nyirokcsomó-áttétet ( $\mathrm{Nl}$ ) adó $\mathrm{Tl}-2$ daganatot reszekálnak (IIIA stádium), a megfelelő utókezelés kiszolgáltatásával a prognózis nagy valószínűséggel jobb. Így érthető az is, hogy például CRC esetén $(\mathrm{n}=99)$ a II. stádiumú alcsoportban $(n=45)$, fóképpen a helyileg előrehaladott esetek (IIC) miatt, az alacsony albuminszintet $(\leq 35 \mathrm{~g} / \mathrm{l})$ mutató páciensek aránya relatíve magas a normális albuminszintet (>35 g/l) mutatókhoz képest: $22,2 \%$ vs. $77,7 \%$. Ez az arány a III. stádiumú alcsoportban $(\mathrm{n}=34)$ a vártnak megfelelően kifejezettebbnek mutatkozott: $32,3 \%$ vs. $67,6 \%$ [46].

A szérumalbumin csökkenését rosszindulatú daganatos páciensek esetében számos tényező előidézheti, például májkárosodás következtében fellépő csökkent albuminszintézis; csökkent aminosavbevitel; heveny vagy idült gyulladással járó betegségek, melyek fokozott albuminvesztéshez vezetnek [47]. Már 1954-ben leírták, hogy a rosszindulatú daganat a plazmafehérjék csapdájaként funkcionál, és a daganatsejtek felhasználják a plazmafehérjék lebontási termékeit a daganatnövekedéshez [48]. Mára az is nyilvánvalóvá vált például, hogy az albuminszintézis üteme nem csökken előrehaladott hasnyálmirigyrákban szenvedő hypoalbuminaemiás páciensekben az egészséges szervezethez képest [49]. Ismeretes, hogy a máj által termelt fehérjék (albumin, prealbumin és transzferrin) tükrözik a tápláltsági állapotot. Ezen fehérjék alacsony szintje az alultápláltság jelzője [1]. Azt is megfigyelték azonban, hogy többhetes éhezés során az albuminszint lényegesen nem változott [29], továbbá gyulladásos folyamatokban, így rosszindulatú daganatokban is, az albuminszint a tápláltsági állapottól függet- 
lenül csökken $[6,50]$. Az emelkedett IL-1, -6, -8 és a TNF fokozzák az akutfázis-fehérjék szintézisét, míg csökkentik az albumintermelést [51-53]. Ismert, hogy a TNF fokozza az érfal áteresztőképességét, aminek hatására az albumin elhagyja az érpályát, így hozzájárul a hypoalbuminaemia kialakulásához [54]. Az albumin érfalon való átjutásának másik módja az ún. caveolaképződés. E fiziológiás sejttranszportfolyamat során a szérumban keringő albumin az endothelsejt caveolin-1-receptorához történő kötődése révén és következményes burok (caveola)-képződés útján jut át az endothelsejtből a szövet közötti térbe. Ezt a tulajdonságát használják fel a nanopartikuláris albuminhoz kötött (nab-) paclitaxel alkalmazásakor [55]. Megfigyelték, hogy gyulladásban a reaktív oxigéngyökök (ROS) képződése által módosulhat az albumin N-terminális régiója. Az így létrejött molekula az ischaemiamódosított albumin (IMA) [56, 57]. Az IMA-szint tájékoztatást ad az albumin csökkent kobaltkötő kapacitásáról, melyet az ún. Bar-Or-féle gyors és kolorimetriás módszer szerint határoznak meg. Jelentősen magasabb IMA-értékeket találtak a kontrollcsoporthoz képest gyomorrákban $(\mathrm{n}=52)$ [58], vastag- és végbélrákban $(\mathrm{CRC})(\mathrm{n}=40)[59]$, prostata- $(\mathrm{n}=25)$ [60] és hólyagrákban $(n=40)[61]$ is. Egy másik vizsgá-

5. táblázat |Az alacsony szérumalbuminszint negatív prognosztikai szerepét feltáró fontosabb vizsgálatok lokalizált rosszindulatú daganatokban

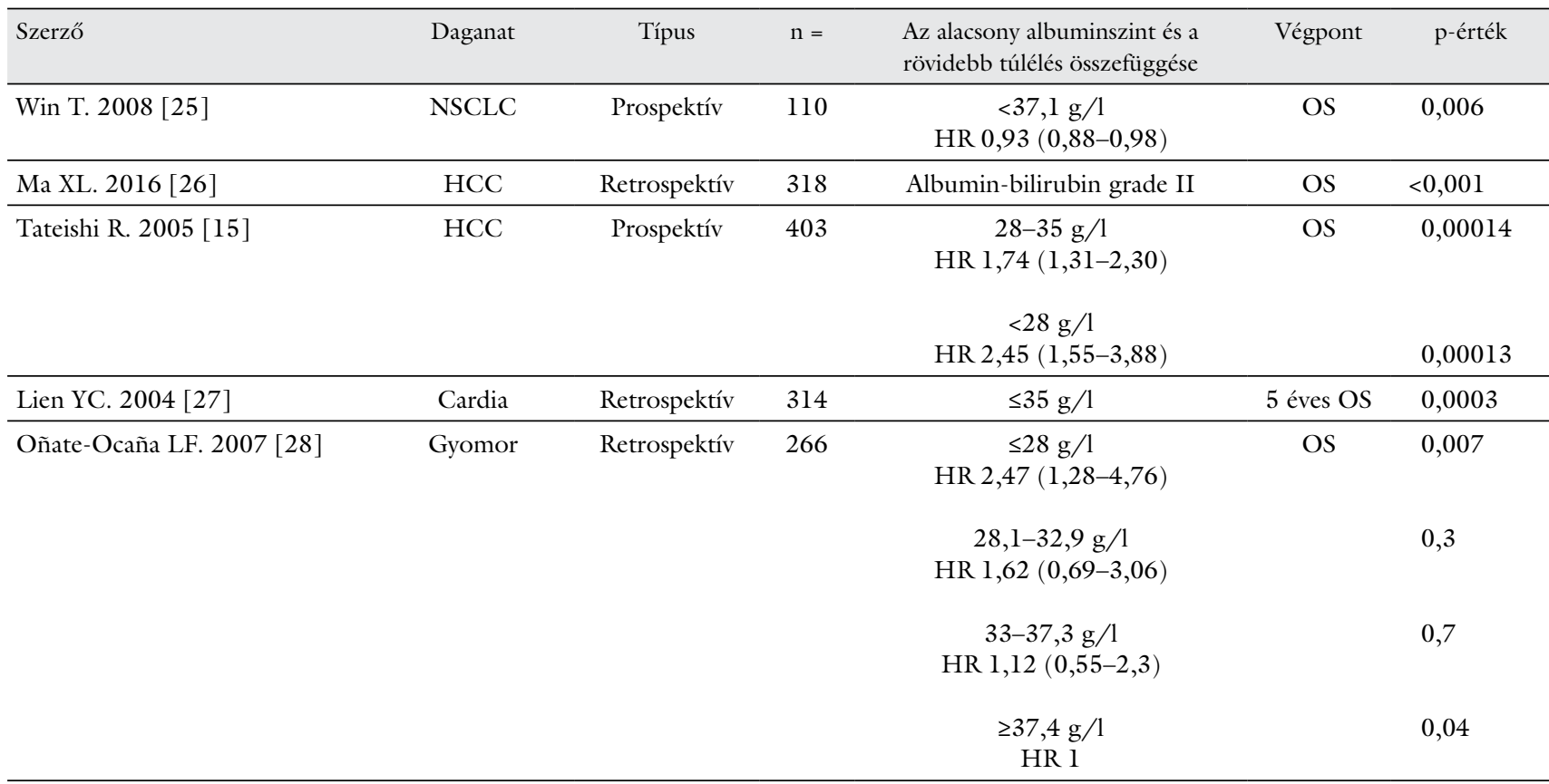

\begin{tabular}{|c|c|c|c|c|c|c|}
\hline Heys SD. 1998 [29] & CRC & Retrospektív & 332 & $\begin{array}{l}\text { Független prognosztikai faktor } \\
\text { HR } 0,94(0,91-0,97)\end{array}$ & OS & $<0,0002$ \\
\hline McMillan DC. 2007 [30] & CRC & Retrospektív & 159 & $\begin{array}{l}\text { mGPS } 0.92 \% \\
\text { mGPS } 1.71 \% \\
\text { mGPS } 2.72 \%\end{array}$ & 3 éves OS & 0,0035 \\
\hline
\end{tabular}

\begin{tabular}{|c|c|c|c|c|c|c|}
\hline Zheng RR. 2017 [31] & Méhnyakrák & Retrospektív & 795 & Független prognosztikai faktor & OS & $<0,05$ \\
\hline Gupta D. 2009 [32] & $\begin{array}{l}\text { Epithelialis } \\
\text { ovarium }\end{array}$ & Retrospektív & 213 & $\leq 35 \mathrm{~g} / 1$ & OS & $<0,001$ \\
\hline Barreto-Andrade JC. 2009 [34] & STS & Retrospektív & 61 & $\begin{array}{l}\qquad<35 \mathrm{~g} / 1 \\
\text { Független prognosztikai faktor } \\
\text { (egy/több változós elemzés) }\end{array}$ & OS & $0,03 / 0,02$ \\
\hline Chang Y. 2015 [10] & $\begin{array}{l}\text { Világossejtes } \\
\text { veserák }\end{array}$ & Retrospektív & 335 & $<40 \mathrm{~g} / 1$ & OS & $<0,001$ \\
\hline Kim HL. 2003 [35] & RCC & Retrospektív & 577 & $\begin{array}{c}<36 \mathrm{~g} / 1 \\
\text { HR 2,3 (CI nem volt megadva) }\end{array}$ & DFS & $<0,0001$ \\
\hline Yap NY. 2013 [36] & RCC & Retrospektív & 101 & $\begin{array}{c}<35 \mathrm{~g} / 1 \\
\text { HR 3,00 }(0,99-8,87)\end{array}$ & DFS & 0,05 \\
\hline Lis CG. 2003 [37] & $\mathrm{BC}$ & Retrospektív & 150 & $<35 \mathrm{~g} / 1$ & 3 éves OS & 0,05 \\
\hline
\end{tabular}

$\mathrm{BC}=$ emlőrák; $\mathrm{CI}=$ konfidenciaintervallum; $\mathrm{CRC}=$ vastag- és végbélrák; $\mathrm{DFS}=$ betegségmentes túlélés; HCC = primer májrák; HR = kockázati hányados; mGPS = módosított Glasgow prognosztikai pontrendszer; NSCLC = nem kissejtes tüdőrák; OS = teljes túlélés; RCC = veserák; STS = lágyrész-sarcoma 
Az alacsony szérumalbuminszint negatív prognosztikai szerepét feltáró fontosabb vizsgálatok helyileg előrehaladott vagy áttétes rosszindulatú daganatokban

\begin{tabular}{|c|c|c|c|c|c|c|c|}
\hline Szerző & Daganat & Típus & $\mathrm{n}=$ & $\begin{array}{l}\text { Az albumin prognoszti- } \\
\text { kai határértéke }(\mathrm{g} / \mathrm{l})\end{array}$ & $\begin{array}{l}\text { Pontrendszer és } \\
\text { prognosztikai értéke }\end{array}$ & Végpont & p-érték \\
\hline Hou JY. 2013 [38] & Nőgyógyászati & Retrospektív & 184 & $\leq 35$ & Nem volt & OS & $<0,001$ \\
\hline $\begin{array}{l}\text { Fox P. } \\
2013[39]\end{array}$ & $\mathrm{RCC}$ & Retrospektív & 362 & $\leq 35$ & Nem volt & OS & $<0,0001$ \\
\hline $\begin{array}{l}\text { Hwang EC. } 2012 \\
{[40]}\end{array}$ & $\begin{array}{l}\text { Helyileg előrehaladott } \\
\text { hólyagrák }\end{array}$ & Retrospektív & 67 & $<35$ & $\begin{array}{l}\text { GPS2 } \\
(\mathrm{OS})\end{array}$ & $\begin{array}{l}\text { PFS } \\
\text { OS }\end{array}$ & $\begin{array}{l}0,023 \\
0,001\end{array}$ \\
\hline $\begin{array}{l}\text { Linton A. } 2013 \\
{[41]}\end{array}$ & Áttétes CRPC & Retrospektív & 220 & $<35$ & mGPS $\geq 1$ & OS & $<0,001$ \\
\hline Jafri SH. 2013 [9] & Áttétes NSCLC & Retrospektív & 173 & Nem volt megadva & $\mathrm{ALI}<18$ & $\begin{array}{l}\text { PFS } \\
\text { OS }\end{array}$ & $\begin{array}{l}0,003 \\
0,047\end{array}$ \\
\hline $\begin{array}{l}\text { Shibutani M. } 2016 \\
{[42]}\end{array}$ & CRC & Retrospektív & 705 & Nem volt megadva & $\begin{array}{l}\text { mGPS0 }(\text { CRP / alb } \\
<0,0271)\end{array}$ & $\begin{array}{l}\text { RFS } \\
\text { CSS }\end{array}$ & $\begin{array}{l}0,0015 \\
0,0131 \\
\end{array}$ \\
\hline $\begin{array}{l}\text { Maretty-Nielsen K. } \\
2014[43]\end{array}$ & STS & Retrospektív & 614 & $<36$ & Nem volt megadva & $\begin{array}{c}\text { DSS } \\
\text { OS }\end{array}$ & $\begin{array}{l}\text { Nem volt } \\
\text { megadva }\end{array}$ \\
\hline
\end{tabular}

$\mathrm{ALI}=$ előrehaladott tüdőrák index; CRC = vastag- és végbélrák; $\mathrm{CRP}=\mathrm{C}$-reaktív protein; CRPC = kasztrációrezisztens prostatarák; CSS = daganatspecifikus túlélés; DSS = betegségspecifikus túlélés; GPS = Glasgow prognosztikai pontrendszer; mGPS = módosított Glasgow prognosztikai pontrendszer; NSCLC = nem kissejtes tüdőrák; OS = teljes túlélés; PFS = progressziómentes túlélés; RCC = veserák; RFS = kiújulásmentes túlélés; STS = lágyrész-sarcoma

latban CRC-ben $(\mathrm{n}=27)$ a mütét előtti IMA-emelkedés korrelált a 'szekvenciális szervelégtelenség felmérés' (SOFA) és a 'heveny élettani és idült egészség értékelés' (APACHE) pontrendszerei által elöre jelzett prognózissal $(\mathrm{p}<0,05)$ [62]. Ugyanakkor az IMA-emelkedés előre jelezheti a doxorubicin okozta szívizom-károsodást is [63].

$\mathrm{Az}$ alacsony albuminszint egyrészt bizonyos kemoterápiás szerek mellékhatásainak fokozódásához vezet, tovább rontva ezáltal a gyenge általános állapotú páciensek életminőségét, másrészt a hypoalbuminaemia más szereknek az ún. harmadik folyadéktérben való felhalmozódásának kedvez, így a szisztémás gyógyszerhatás romlik, ami a daganat progresszióját segíti elő. Ismert, hogy az albumin szérumkoncentrációjában kialakuló eltéréseknek (hypo- vagy hyperalbuminaemia) klinikai farmakológiai jelentőségük van. A gyógyszerek fehérjekötődése szempontjából a legjelentősebb az albumin, mivel ennek az össztömege lényegesen meghaladja a többi plazmafehérjéét (globulinok, transzferrin, cöruloplazmin, glikoproteinek, alfa- és béta-lipoproteinek). Az albumin azáltal befolyásolja a gyógyszer eloszlását, kiürülését és metabolizmusát, hogy a hozzá kapcsolódott vegyület nem tudja elhagyni az érpályát, így nem jut el a hatás és a metabolizmus helyére. Egy albuminmolekulához két savanyú gyógyszermolekula kötődhet, azonban kisebb kötési erősséggel, de több bázikus jellegü molekula kapcsolódhat hozzá. Mivel a gyógyszerkötési helyek nem teljesen specifikusak az albuminmolekulán, két vagy több gyógyszer együttes adása során interakció (kompetíció) alakulhat ki. Az albuminról való leszorítás a nagyon erősen kötődő vegyületek esetében (például warfarin) várható. Jóllehet ebben az esetben a szabadgyógyszer-koncentráció növekedése még nagymértékü kompetíció esetén is legfeljebb 3-5\%-os lehet, ami a teljes eloszlási térfogatban történő felhígulása folytán, lényegtelen szabad koncentrációváltozást eredményez a hatás helyén. A szabadgyógyszer-koncentráció emelkedésével, változatlan clearance mellett, a kiürülő gyógyszer mennyisége is növekszik [64], így négy fél életidő alatt a szabadgyógyszer-koncentráció visszatér az előző egyensúlyi értékre. Ennek magyarázata az, hogy a kötött gyógyszerraktárból visszapótlódik a kiürült gyógyszermennyiségnek megfelelő szabad gyógyszer. Az albuminról való leszorításért felelős gyógyszer egyúttal a clearance gátlásáért is felel, és valójában a szabadgyógyszer-clearance csökkenése magyarázza az interakció mechanizmusát. Jóllehet az alacsony albuminszint mellett a teljes gyógyszerkoncentráció is alacsonyabb lesz, az egyensúlyra való törekvés miatt a szabadgyógyszer-koncentráció nem változik [65]. Az albuminhoz való kötődés megváltozásának az ún. keskeny terápiás indexszel és magas clearance-szel rendelkező gyógyszerek esetén van jelentősége, melyeket intravénásan alkalmaznak (például lidokain). Amikor az albuminkötődés megváltozik, a szabad gyógyszer azonnal kiegyenlíti a koncentrációkülönbséget az egész szervezetben, így csak átmenetileg változik meg jelentős mértékben a szabadgyógyszer-szint. Kizárólag olyan gyógyszereknél mutatható ki mérhető hatás, melyeknél a szabadplazma-koncentráció változásával szinte azonnal módosul a hatás is (például antiarrythmiás szerek) [66]. A plazmafehérjékhez való kötődés módosíthatja a citotoxikus vegyületek farmakokinetikáját is. Az albuminszintcsökkenés abban az esetben bírhat jelentőséggel, amikor a gyógyszer nagy affinitást mutat a fehérjék iránt [67]. Az etopozid okozta toxicitás fokozódását figyelték meg például előrehaladott májbetegség miatt kialakult alacsony albuminszint esetén [66]. A rosszindulatú dagana- 
tos betegeknél a daganatellenes szerek farmakokinetikáját befolyásolhatja az ún. harmadik folyadéktérben való gyógyszermegoszlás (például oedema, ascites, pleuralis folyadékgyülem) is. A metotrexát eliminációja elhúzódhat a szabad hasûri folyadékban történő felhalmozódás miatt [67]. Alacsony albuminszint esetén $(<35 \mathrm{~g} / \mathrm{l})$ a nab-paclitaxel maximális eliminációs sebessége 12\%-kal csökken a normális albuminszinttel rendelkező páciensekhez képest, így a nab-paclitaxel hosszabb ideig marad a keringésben [68].

$\mathrm{Az}$ albuminpótlás pozitív hatását igazolták néhány speciális betegcsoportban, például szeptikus shockban szenvedő betegek azon eseteiben, amikor kolloidpótlásra is szükség van. A hypoalbuminaemia korrekciója megfontolandó továbbá májzsugorban és spontán bakteriális peritonitis fennállása esetén, l-es típusú hepatorenalis szindrómában, valamint akut respiratorikus distresszszindrómában, amikor a plazma oncoticus nyomása alacsony [69]. A rendelkezésre álló kontrollált klinikai vizsgálatok eredményei alapján azonban az albuminpótlás nem befolyásolja jelentős mértékben a kritikus állapotú páciensek, beleértve a rosszindulatú daganatos betegek morbiditását [70].

A táplálásterápiának (ezzel együtt az albuminszintemelkedésnek) a rosszindulatú daganatban szenvedő betegekre gyakorolt pozitív hatásáról számos közlemény jelent meg eddig a szakirodalomban. Például NSCLCben $(\mathrm{n}=58)$ kuratív mútét után kisebb volt az albuminszint-csökkenés aránya azoknál, akik preoperatíve táplálásterápiában részesültek ( $14 \%$ vs. 25\%). Mindkét karon lévő pácienseknél jó tápláltsági állapotot rögzítettek a mútét előtt. A táplálásterápiában részesülőkk körében kevesebb volt a mútét utáni komplikációk aránya (10,3\% vs. $44,4 \% ; \mathrm{p}=0,049)$. A szerzők javasolták, hogy a mútét utáni albuminszint normális tartományban tartásához $(\geq 35 \mathrm{~g} / \mathrm{l})$ a preoperatíve mért $<45 \mathrm{~g} / \mathrm{l}$ albuminszint esetén táplálásterápia bevezetését tartották szükségesnek [71]. Figyelemre méltó, hogy lokalizált rosszindulatú daganatos betegségekben a normális BMI-érték melletti alacsony albuminszint rossz prognózist vetít előre, míg a BMI-értéknek az esetek nagyobb részében nincs prognosztikus értéke [25, 31, 32, 34, 37]. Gyomorrákban $(\mathrm{n}=830)$ a kemoterápiás kezelés alatt alkalmazott táplálásterápia azoknál a pácienseknél jelentett túlélési előnyt, akiknél a kiindulási tápláltsági kockázatszúrés (NRS) pontszáma $<3$ volt (átlagos túlélés 31,9 vs. 25,7 hó; $\mathrm{p}<0,001$ ). Amennyiben a kiinduláskor számított NRS $\geq 3$ volt, abban az esetben változott nagy valószínúséggel a $\mathrm{NRS}<3$, ha a kemoterápiás kezelésre jól reagáló fiatal férfi pácienseknél alkalmaztak táplálásterápiát. Az átlagos túlélés hosszabb volt azoknál, akiknek a NRS-értéke javult $(14,3$ vs. 9,6 hó; $\mathrm{p}=0,001)[72]$.

\section{Következtetés}

A szakirodalmi adatok alapján a rosszindulatú daganatos betegségek rosszabb prognózisával korrelál a kiindulási alacsony szérumalbuminszint. Számos prognosztikai pontrendszer tartalmazza az albumint. A táplálásterápia (ezzel együtt az albuminszint-emelkedés) javítja a rosszindulatú daganatos betegségben szenvedők túlélését és életminőségét.

Anyagi támogatás: A publikáció megírásához a szerzők anyagi támogatásban nem részesültek.

Szerzöi munkamegosztás: D. D.: A közlemény szövegének megszerkesztése és gondozása. T. A.: A korábbi kéziratváltozatok áttekintése és kiegészítése. A cikk végleges változatát a szerzők elolvasták és jóváhagyták.

Érdekeltségek: A szerzőknek nincsenek érdekeltségeik.

\section{Irodalom}

[1] Nazha B, Moussaly E, Zaarour M, et al. Hypoalbuminemia in colorectal cancer prognosis: Nutritional marker or inflammatory surrogate? World J Gastrointest Surg. 2015; 7: 370-377.

[2] Schmid M, Schindler R, Weigand K, et al. Is albumin synthesis regulated by the colloid osmotic pressure? Effect of albumin and dextran on albumin and total protein synthesis in isolated rat hepatocytes. Klin Wochenschr. 1986; 64: 23-28.

[3] Seaton K. Albumin concentration controls cancer. J Natl Med Assoc. 2001; 93: 490-493.

[4] Peters T. Metabolism: Albumin in the body. In: All about albumin: biochemistry, genetics and medical applications. Academic Press Limited, San Diego, CA, 1996; p. 232.

[5] Barber MD, Ross, JA, Fearon KC. Changes in nutritional, functional, and inflammatory markers in advanced pancreatic cancer. Nutr Cancer 1999; 35: 106-110.

[6] McMillan DC, Watson WS, O'Gorman P, et al. Albumin concentrations are primarily determined by the body cell mass and the systemic inflammatory response in cancer patients with weight loss. Nutr Cancer 2001; 39: 210-213.

[7] Deme D, Telekes A. Prognostic importance of plasma C-reactive protein (CRP) in oncology. [A C-reaktív protein (CRP) plazmaszintjének prognosztikai jelentősége az onkológiában.] Orv Hetil. 2017; 158: 243-256. [Hungarian]

[8] Ahmad J, Grimes N, Farid S, et al. Inflammatory response related scoring systems in assessing the prognosis of patients with pancreatic ductal adenocarcinoma: a systematic review. Hepatobiliary Pancreat Dis Int. 2014; 13: 474-481.

[9] Jafri SH, Shi R, Mills G. Advance lung cancer inflammation in$\operatorname{dex}(\mathrm{ALI})$ at diagnosis is a prognostic marker in patients with metastatic non-small cell lung cancer (NSCLC): a retrospective review. BMC Cancer 2013; 13: 158.

[10] Chang Y, An H, Xu L, et al. Systemic inflammation score predicts postoperative prognosis of patients with clear-cell renal cell carcinoma. Br J Cancer 2015; 113: 626-633.

[11] Hutterer GC, Stoeckigt C, Stojakovic T, et al. Low preoperative lymphocyte-monocyte ratio (LMR) represents a potentially poor prognostic factor in nonmetastatic clear cell renal cell carcinoma. Urol Oncol. 2014; 32: 1041-1048.

[12] Szkandera J, Gerger A, Liegl-Atzwanger B, et al. The lymphocyte/monocyte ratio predicts poor clinical outcome and improves the predictive accuracy in patients with soft tissue sarcomas. Int J Cancer 2014; 135: 362-370.

[13] Cai W, Zhang J, Chen Y, et al. Association of post-treatment hypoalbuminemia and survival in Chinese patients with metastatic renal cell carcinoma. Chin J Cancer 2017; 36: 47. 
[14] Deme D, Telekes A. Prognostic importance of lactate dehydrogenase (LDH) in oncology. [A laktátdehidrogenáz (LDH) prognosztikai jelentősége az onkológiában.] Orv Hetil. 2017; 158: 1977-1988. [Hungarian]

[15] Tateishi R, Yoshida H, Shiina S, et al. Proposal of a new prognostic model for hepatocellular carcinoma: an analysis of $403 \mathrm{pa}-$ tients. Gut 2005; 54: 419-425.

[16] Johnson PJ, Berhane S, Kagebayashi C, et al. Assessment of liver function in patients with hepatocellular carcinoma: a new evidence-based approach - the ALBI grade. J Clin Oncol. 2015; 33: $550-558$.

[17] Dirican N, Dirican A, Anar C, et al. A new inflammatory prognostic index, based on C-reactive protein, the neutrophil to lymphocyte ratio and serum albumin is useful for predicting prognosis in non-small cell lung cancer cases. Asian Pac J Cancer Prev. 2016; 17: 5101-5106.

[18] Gupta D, Lis CG. Pretreatment serum albumin as a predictor of cancer survival: A systematic review of the epidemiological literature. Nutr J. 2010, 9: 69.

[19] McMillan DC. The systemic inflammation-based Glasgow Prognostic Score: a decade of experience in patients with cancer. Cancer Treat Rev. 2013; 39: 534-540.

[20] Partridge M, Fallon M, Bray C, et al. Prognostication in advanced cancer: a study examining an inflammation-based score. J Pain Symptom Manage. 2012; 44: 161-167.

[21] Li MX, Bi XY, Li ZY, et al. Prognostic role of Glasgow Prognostic Score in patients with hepatocellular carcinoma: A systematic review and meta-analysis. Medicine (Baltimore) 2015; 94: e2133.

[22] Petrelli F, Barni S, Coinu A, et al. The Modified Glasgow Prognostic Score and survival in colorectal cancer: A pooled analysis of the literature. Rev Recent Clin Trials 2015; 10: 135-141.

[23] Chen Z, Shao Y, Wang K. Prognostic role of pretreatment serum albumin in renal cell carcinoma: a systematic review and metaanalysis. Onco Targets Ther. 2016; 9: 6701-6710.

[24] Miao Y, Li S, Yan Q, et al. Prognostic significance of preoperative prognostic nutritional index in epithelial ovarian cancer patients treated with platinum-based chemotherapy. Oncol Res Treat. 2016; 39: 712-719.

[25] Win T, Sharples L, Groves AM, et al. Predicting survival in potentially curable lung cancer patients. Lung 2008; 186: 97-102.

[26] Ma XL, Zhou JY, Gao XH, et al. Application of the albuminbilirubin grade for predicting prognosis after curative resection of patients with early-stage hepatocellular carcinoma. Clin Chim Acta 2016; 462: 15-22.

[27] Lien YC, Hsieh CC, Wu YC, et al. Preoperative serum albumin level is a prognostic indicator for adenocarcinoma of the gastric cardia. J Gastrointest Surg. 2004; 8: 1041-1048.

[28] Oñate-Ocaña LF, Aiello-Crocifoglio V, Gallardo-Rincon D, et al. Serum albumin as a significant prognostic factor for patients with gastric carcinoma. Ann Surg Oncol. 2007; 14: 381-389.

[29] Heys SD, Walker LG, Deehan DJ, et al. Serum albumin: a prognostic indicator in patients with colorectal cancer. J R Coll Surg Edinb. 1998; 43: 163-168.

[30] McMillan DC, Crozier JE, Canna K, et al. Evaluation of an inflammation-based prognostic score (GPS) in patients undergoing resection for colon and rectal cancer. Int J Colorectal Dis. 2007; 22 : 881-886

[31] Zheng RR, Huang XW, Liu WY, et al. Nomogram predicting overall survival in operable cervical cancer patients. Int J Gynecol Cancer 2017; 27: 987-993

[32] Gupta D, Lammersfeld CA, Vashi PG, et al. Is serum albumin an independent predictor of survival in ovarian cancer? Clin Ovarian Cancer 2009; 2: 52-56.

[33] Clark TG, Stewart ME, Altman DG, et al. A prognostic model for ovarian cancer. Br J Cancer 2001; 85: 944-952.

[34] Barreto-Andrade JC, Medina-Franco H. Serum albumin is an independent prognostic factor for survival in soft tissue sarcomas. Rev Invest Clin. 2009; 61: 198-204.
[35] Kim HL, Belldegrun AS, Freitas DG, et al. Paraneoplastic signs and symptoms of renal cell carcinoma: implications for prognosis. J Urol. 2003; 170: 1742-1746.

[36] Yap NY, Ng KL, Ong TA, et al. Clinical prognostic factors and survival outcome in renal cell carcinoma patients - a Malaysian single centre perspective. Asian Pac J Cancer Prev. 2013; 14: 7497-7500.

[37] Lis CG, Grutsch JF, Vashi PG, et al. Is serum albumin an independent predictor of survival in patients with breast cancer? J Parenter Enteral Nutr. 2003; 27: 10-15.

[38] Hou JY, Aparo S, Ghalib M, et al. Clinical outcome and prognostic markers for patients with gynecologic malignancies in phase 1 clinical trials: A single institution experience from 1999 to 2010. Gynecol Oncol. 2013; 131: 163-168.

[39] Fox P, Hudson M, Brown C, et al. Markers of systemic inflammation predict survival in patients with advanced renal cell cancer. Br J Cancer 2013; 109: 147-153.

[40] Hwang EC, Hwang IS, Yu HS, et al. Utility of inflammationbased prognostic scoring in patients given systemic chemotherapy first-line for advanced inoperable bladder cancer. Jpn J Clin Oncol. 2012; 42: 955-960.

[41] Linton A, Pond G, Clarke S, et al. Glasgow Prognostic Score as a prognostic factor in metastatic castration-resistant prostate cancer treated with docetaxel-based chemotherapy. Clin Genitourin Cancer 2013; 11: 423-430.

[42] Shibutani M, Maeda K, Nagahara H, et al. Prognostic significance of the preoperative ratio of $\mathrm{C}$-reactive protein to albumin in patients with colorectal cancer. Anticancer Res. 2016; 36: 995-1001.

[43] Maretty-Nielsen K. Prognostic factors in soft tissue sarcoma. Population-based studies on comorbidity, biomarkers, and methodological aspects. Dan Med J. 2014; 61: B4957.

[44] Nemeth E, Rivera S, Gabayan V, et al. IL-6 mediates hypoferremia of inflammation by inducing the synthesis of the iron regulatory hormone hepcidin. J Clin Invest. 2004; 113: 1271-1276.

[45] Nieken J, Mulder NH, Buter J, et al. Recombinant human interleukin-6 induces a rapid and reversible anemia in cancer patients. Blood 1995; 86: 900-905.

[46] Cengiz O, Kocer B, Sürmeli S, et al. Are pretreatment serum albumin and cholesterol levels prognostic tools in patients with colorectal carcinoma? Med Sci Monit. 2006; 12: CR240CR247.

[47] Don BR, Kaysen G. Serum albumin: relationship to inflammation and nutrition. Semin Dial. 2004; 17: 432-437.

[48] Babson AL, Winnick T. Protein transfer in tumor-bearing rats. Cancer Res. 1954; 14: 606-611.

[49] Fearon KC, Falconer JS, Slater C, et al. Albumin synthesis rates are not decreased in hypoalbuminemic cachectic cancer patients with an ongoing acute-phase protein response. Ann Surg. 1998; 227: 249-254.

[50] Don BR, Kaysen GA. Assessment of inflammation and nutrition in patients with end-stage renal disease. J Nephrol. 2000; 13: 249-259.

[51] Gabay C, Kushner I. Acute-phase proteins and other systemic responses to inflammation. N Engl J Med. 1999; 340: 448-454.

[52] Castell JV, Gomez-Lechon MJ, David M, et al. Acute-phase response of human hepatocytes: Regulation of acute-phase protein synthesis by interleukin-6. Hepatology 1990; 12: 1179-1186.

[53] Chojkier M. Inhibition of albumin synthesis in chronic diseases: molecular mechanisms. J Clin Gastroenterol. 2005; 39(4 Suppl 2): S143-S146.

[54] Fanali G, di Masi A, Trezza V, et al. Human serum albumin: from bench to bedside. Mol Aspects Med. 2012; 33: 209-290.

[55] Vaz J, Ansari D, Sasor A, et al. SPARC: a potential prognostic and therapeutic target in pancreatic cancer. Pancreas 2015; 44: 1024-1035.

[56] Cichota LC, Moresco RN, Duarte MM, et al. Evaluation of ischemia-modified albumin in anemia associated to chronic kidney disease. J Clin Lab Anal. 2008; 22: 1-5. 
[57] Roy D, Quiles J, Gaze DC, et al. Role of reactive oxygen species on the formation of the novel diagnostic marker ischaemia mod ified albumin. Heart 2006; 92: 113-114.

[58] Fidan E, Mentese A, Kavgaci H, et al. Increased ischemia-modified albumin levels in patients with gastric cancer. Neoplasma 2012; 59: 393-397.

[59] Ellidag HY, Bulbuller N, Eren E, et al. Ischemia-modified albumin: could it be a new oxidative stress biomarker for colorectal carcinoma? Gut Liver 2013; 7: 675-680.

[60] Da Silveira RA, Hermes CL, Almeida TC, et al. Ischemia-modified albumin and inflammatory biomarkers in patients with prostate cancer. Clin Lab. 2014; 60: 1703-1708.

[61] Ellidag HY, Eren E, Aydin O, et al. Ischemia modified albumin levels and oxidative stress in patients with bladder cancer. Asian Pac J Cancer Prev. 2013; 14: 2759-2763.

[62] Satoh M, Kotani K, Gugliucci A, et al. Correlation of ischemiamodified albumin with SOFA and APACHE II scores in preoperative patients with colorectal cancer. Sci World J. 2014; 2014: 959075.

[63] Ma Y, Kang W, Bao Y, et al. Clinical Significance of ischemiamodified albumin in the diagnosis of doxorubicin-induced myocardial injury in breast cancer patients. PLoS ONE 2013; 8: e79426.

[64] Magyar K, Tóthfalusi L. Fate of drugs in the human body. Pharmacokinetics. In: Gyires K, Fürst Zs. (eds.) Principles of pharmacology. [A gyógyszerek sorsa a szervezetben. Farmakokinetika. In: Gyires K, Fürst Zs. (szerk.) A farmakológia alapjai.] Medicina Könyvkiadó, Budapest, 2011; pp. 67-68. [Hungarian]

[65] Nicholas HG, Holford MB. Pharmacokinetics \& Pharmacodynamics: Rational Dosing \& the Time Course of Drug Action. In: Katzung BG, Masters SB, Trevor AJ. (eds.) Basic \& Clinical Pharmacology. 12th edn. McGraw-Hill Companies, Inc., San Fancisco, CA, 2012; p. 49
[66] Buxton IL, Benet LZ. Pharmacokinetics: The Dynamics of Drug Absorption, Distribution, Metabolism, and Elimination. In: Brunton LL. (ed.) Goodman \& Gilman's The Pharmacological Basis of Therapeutics. 12th edn. McGraw-Hill Companies, Inc., San Fancisco, CA, 2011; p. 43

[67] Kovács P, Kralovánszky J, Kovács G, et al. Pharmacokinetics. In: Jeney A, Kralovánszky J. (eds.) Oncopharmacology. [Farmakokinetika. In: Jeney A, Kralovánszky J. (szerk.) Onkofarmakológia.] Medicina Könyvkiadó, Budapest, 2009; p. 189. [Hungarian]

[68] Chen N, Li Y, Ye Y, et al. Pharmacokinetics and pharmacodynamics of nab-paclitaxel in patients with solid tumors: disposition kinetics and pharmacology distinct from solvent-based paclitaxel. J Clin Pharmacol. 2014; 54: 1097-1107.

[69] Vincent JL, Russell JA, Jacob M, et al. Albumin administration in the acutely ill: what is new and where next? Crit Care 2014; 18: 231.

[70] Vincent JL, Dubois MJ, Navickis RJ, et al. Hypoalbuminemia in acute illness: is there a rationale for intervention? A meta-analysis of cohort studies and controlled trials. Ann Surg. 2003; 237: 319-334

[71] Kaya SO, Akcam TI, Ceylan KC, et al. Is preoperative proteinrich nutrition effective on postoperative outcome in non-small cell lung cancer surgery? A prospective randomized study. J Cardiothorac Surg. 2016; 11: 14.

[72] Qiu M, Zhou YX, Jin Y, et al. Nutrition support can bring survival benefit to high nutrition risk gastric cancer patients who received chemotherapy. Support Care Cancer 2015; 23: 19331939

(Deme Dániel dr., Salgótarján, Füleki út 54-56., 3100 e-mail: danieldeme_md@ymail.com)

\section{A Magyar Endokrinológiai és Anyagcsere Társaság (MEAT) pályázatot hirdet a 2018. évi MEAT Ifjúsági Díjra}

Pályázati feltételek:

(1) A pályázó életkora a pályázat beadásakor nem haladhatja meg a 35 évet.

(2) Pályázni lehet a tárgyévben vagy az azt megelőző évben megjelent vagy közlésre elfogadott dolgozattal. Ha a pályázónak több közleménye is megfelel a feltételeknek, a pályázó választása szerinti egyetlen közleménnyel lehet jelentkezni.

(3) A pályázatra benyújtott dolgozat témájának az endokrinológia vagy a neuroendokrinológia tárgykörébe kell tartoznia.

(4) Hazai laboratóriumban készült és önállóan végzett munka elönyben részesül.

(5) Többszerzős munka esetén a pályázó a dolgozat első szerzője kell legyen.

(6) 2017-ben, vagy azt megelőzően létesített MEAT tagság, 2018-ig rendezett tagdíj.

Az Ifjúsági Díjat évente egy pályázó nyerheti el, a Dij díszoklevélből és pénzjutalomból áll (150 000 forint). A díj odaítélésére a MEAT elnöke által felkért bíráló bizottság tesz javaslatot, a végleges döntést a MEAT vezetősége hozza meg.

A pályázat beküldési határideje: 2017. április 15.

A nyertes pályázó dolgozatát a MEAT 2018. évi kongresszusán ismerteti. A pályázatot a MEAT főtitkárához (Prof. Dr. Tóth Miklós, Semmelweis Egyetem, II. Belgyó-gyászati Klinika, toth.miklos@med.semmelweis-univ.hu) kell benyújtani (pályázat + megjelent/elfogadott dolgozat elektronikus változata + szakmai önéletrajz). A pályázónak nyilatkoznia kell, hogy a társszerzőket előzetesen értesítette a dolgozat pályázatra történő benyújtásáról. 